\title{
Analisis Pemahaman Mahasiswa Matematika terhadap Konsep Garis dan Sudut
}

\author{
Udiyono $^{1}$, Muhammad Ridlo Yuwono ${ }^{2}$
}

1,2Universitas Widya Dharma Klaten, Indonesia

Correspondence: \udiyono@unwidha.ac.id

\begin{tabular}{|c|c|}
\hline Article Info & Abstract \\
\hline $\begin{array}{l}\text { Article History } \\
\text { Received :13-11-2019 } \\
\text { Revised :26-11-2019 } \\
\text { Accepted : 30-11-2019 } \\
\text { Keywords: } \\
\text { Understanding; Line; } \\
\text { Angels. }\end{array}$ & $\begin{array}{l}\text { This study aims to determine the level of understanding of mathematics student on } \\
\text { line and angle material and their causes. This research is a case study. Subjects were } \\
\text { selected using purposive sampling technique. This research instrument is an } \\
\text { understanding test and interview guidelines. Method triangulation techniques are } \\
\text { used to compare the results of understanding tests with interviews. Data analysis } \\
\text { for understanding test results using a percentage level of understanding formula. } \\
\text { Data analysis for interview results is data reduction, data presentation and } \\
\text { conclusion drawing. The results showed that the level of achievement of the six } \\
\text { aspects of understanding was less than } 30 \% \text {. The conclusions of this study are the } \\
\text { level of understanding of mathematics students in the material line and angle is still } \\
\text { low. }\end{array}$ \\
\hline
\end{tabular}

\section{PENDAHULUAN}

Mahasiswa yang mengambil program studi pendidikan matematika, diproyeksikan menjadi guru matematika di sekolah. Mahasiswa sebagai calon guru, sudah seharusnya senantiasa mengembangkan kompetensi profesionalnya dengan cara mempelajari serta memahami secara baik kompetensi yang ada di mata pelajaran matematika dan bagaimana cara mengajarkannya kepada siswa.

Geometri merupakan salah satu cabang matematika yang terdapat pada kompetensi mata pelajaran matematika di sekolah. Calon guru matematika haruslah memahami dengan baik konsep-konsep dasar geometri secara baik. Jika tidak memahami suatu konsep, maka dikhawatirkan akan kesulitan untuk memahami konsep-konsep berikutnya serta memecahkan masalah yang berkaitan dengan konsep tersebut.

Pada awal perkualiahan Program Studi Pendidikan Matematika Universitas Widya Dharma Klaten, mahasiswa harus mengikuti mata kuliah geometri dasar terlebih dahulu. Mata kuliah ini merupakan mata kuliah prasyarat untuk mengambil mata kuliah geometri ruang dan geometri analitik. Akan tetapi, hasil penelitian Yuwono [1] menunjukkan bahwa mahasiswa masih mengalami kesulitan pada mata kuliah geometri berdasarkan taksonomi Bloom. Mahasiswa masih mengalami kesulitan pada tingkat pemahaman, tingkat penerapan, tingkat analisis, dan tingkat evaluasi. Kesulitan mahasiswa pada mata kuliah geometri diantaranya adalah kesulitan dalam menentukan garis tinggi jajargenjang dan kesulitan dalam menerapkan konsep kesebangunan untuk memecahkan masalah.

Sejalan dengan penelitian Yuwono [1], hasil penelitian Ayvaz, Gündüz dan Bozkuş [2] menunjukkan bahwa mahasiswa sebagai calon guru matematika masih belum memahami konsep diagonal segiempat dengan baik. Mereka juga kesulitan untuk membuktikan gagasan mereka, meskipun gagasan mereka benar. Hasil penelitian Tarigan menunjukkan bahwa mahasiswa Pendidikan Guru Sekolah Dasar (PGSD) cenderung melakukan kesalahan dalam mengerjakan soal geometri disebabkan kesalahan prosedur [3]. Imswatama dan Muhassanah [4] dalam penelitiannnya menyatakan bahwa mahasiswa mengalami kesulitan dalam mengerjakan soal geometri analitik materi garis dan lingkaran. Kesulitan tersebut meliputi kesulitan memahami masalah, kesulitan prosedur penyelesaian masalah, dan kesulitan menghafalkan rumus. Mahasiswa juga sering mengalami kesulitan pada mata kuliah geometri transformasi. Hal tersebut dibuktikan berdasarkan hasil penelitian Ada dan Kurtulus [5] yang menyatakan bahwa pada materi translasi dan rotasi mahasiswa mengetahui makna dari aljabarnya, akan tetapi secara geometris tidak mengetahui maknanya. 
Berdasarkan beberapa hasil penelitian tesebut, dapat dibuat rangkuman kesulitan-kesulitan mahasiswa sebagai calon guru matematika pada materi geometri sebagai berikut.Kesulitan yang pertama adalah kesulitan dalam memecahkan soal geometri pada tingkat pemahaman, penerapan, dan analisis pada tahapan Taksonomi Bloom. Kesulitan yang kedua adalah kesulitan dalam mahasiswa kesulitan membuktikan gagasannya dalam pembuktian pada materi geometri, meskipun gagasannya itu benar. Kesulitan ketiga adalah kesulitan dalam memahami masalah dan menerapkan prosedur untuk memecahkan masalah geometri. Kesulitan keempat adalah kesulitan dalam memaknai tinjauan geometris, dan hanya memahami makna aljabarnya saja dalam memecahkan masalah geometri.

Apabila permasalahan tersebut tidak diidentifikasi sedini mungkin dan dicari penyelesaiannya, maka dikhawatirkan dapat menimbulkan dampak yang tidak baik bagi pemahaman siswa terhadap geometri. Jika pemahaman siswa rendah, maka dapat diprediksi siswa akan kesulitan dalam memecahkan masalah geometri dari yang sederhana hingga ke masalah yang lebih kompleks.

Berikut merupakan kesulitan-kesulitan yang timbul pada siswa dalam memecahkan masalah geometri berdasarkan hasil penelitian dari beberapa peneliti. Hasil penelitian Sholihah dan Afriansyah [6] menunjukkan bahwa kebanyakan siswa dalam memecahkan masalah geometri berdasarkan tahapan berpikir Van Hiele hanya sampai pada tahap visualisasi. Hanya sedikit siswa yang sampai pada tahap analisis.Belum terdapat siswa yang sudah mencapai tahap deduksi formal dan deduksi informal. Hasil penelitian Mutia [7] menunjukkan bahwa siswa mengalami kesulitan dalam memahami konsep kubus balok dan menggunakan rumus luas permukaan kubus balok. Kesulitan dalam menghafal rumus tersebut dikarenakan siswa dibiasakan untuk menggunakan rumus siap pakai untuk memecahkan masalah.

Hasil penelitian Yuwono [8] menunjukkan bahwa terdapat tiga jenis kesulitan belajar siswa dalam mengerjakan soal segitiga. Jenis kesulitan yang pertama adalah kesulitan dalam memahami konsep segitiga, seperti konsep alas dan tinggi segitiga.Jenis kesulitan yang kedua adalah kesulitan mengidentifikasi dan menyebutkan sifat-sifat segitiga. Jenis kesulitan yang ketiga adalah kesulitan dalam membuktikan rumus jumlah besar sudut segitiga adalah seratus delapan puluh derajat. Penelitian tersebut juga sejalan dengan penelitian Mahdayani [9], yang menyatakan bahwa siswa kesulitan dalam memahami soal geometri, mengembangkan keterampilan proses, dan menarik kesimpulan. Siswa juga kesulitan dalam materi garis berat segitiga sebagaimana hasil penelitian Soewardini dan Meilantif [10] yang menyatakan bahwa siswa kesulitan dalam menyesuaikan dan memodifikasi informasi baru tentang garis berat baik pada aktiftas siswa dan proses asimilasi dan akomodasi. Selain itu, juga ditemukan miskonsepsi siswa kelas VII pada materi geometri. Hasil penelitian Özerem [11] menunjukkan bahwa siswa kelas VII memiliki sejumlah kesalahpahaman, kurangnya latar belakang pengetahuan dan penalaran, serta kesalahan operasi dasar pada materi geometri.

Siswa kelas VIII pun juga mengalami kesalahpahaman pada materi geometri khususnya tentang sudut. Hasil penelitian Biber, Tuna, dan Korkmaz [12] menunjukkan bahwa, (1) siswa hanya memperhatikan penampilan fisik objek geometris saja tanpa memperhatikan sifat geometrisnya; (2) meskipun mereka mendeteksi beberapa sifat geometris dari gambar, mereka gagal mengaitkan sifat-sifat ini dengan pengetahuan lain yang diperlukan untuk pemecahan; (3) siswa menggeneralisasi properti yang hanya berlaku untuk kondisi spesifik pada situasi yang berbeda; (4) dan siswa belum sepenuhnya memahami konsep kesejajaran yang berkaitan dengan sudut.

Beberapa jenis kesulitan siswa pada materi geometri yang telah disebutkan oleh penelitian terdahulu merupakan jenis kesulitan yang mendasar dan berkaitan dengan konsep. Jika siswa belum memahmai konsep secara baik, maka dikhawatirkan siswa akan sulit mengaitkan pengetahuan yang satu dengan pengetahuan yang lain dalam rangka memecahkan masalah geometri. Materi dasar yang perlu dipelajari dalam geometri adalah konsep dan definisi dari garis dan sudut. Dua materi dasar tersebut sangat diperlukan dalam mempelajari materi geometri yang lainnya, seperti relasi sudut-sudut yang terbentuk dari dua buah garis yang sejajar. Materi relasi sudut-sudut yang terbentuk dari dua buah garis yang sejajar dapat digunakan untuk mengidentifikasi jumlah sudut dalam suatu segitiga, untuk mengidentifikasi hubungan sudut-sudut segiempat, ataupun digunakan untuk materi geometri lainnya. Mahasiswa sebagai calon guru matematika seharusnya mampu memahami dua materi tersebut dengan baik supaya dapat mempelajari materi geometri yang lainnya dengan baik pula. Jika tidak memahami materi itu dengan baik, maka akan dikhawatirkan muncul kesulitan yang mendasar dasar geometri, seperti kesulitan dalam menentukan garis tinggi jajargenjang dan kesulitan dalam menerapkan konsep kesebangunan untuk memecahkan masalah belum 
memahami konsep diagonal segiempat dengan baik [2], serta kesulitan dalam mengerjakan soal geometri analitik materi garis dan lingkaran [4]. Oleh karena itu, perlu dilakukan penelitian untuk menganalisis pemahaman mahasiswa sebagai calon guru matematika terhadap konsep garis dan sudut.

\section{METODE}

Penelitian ini termasuk dalam penelitian studi kasus. Pada penelitian ini, studi kasus yang dimaksud adalah mendeskripsikan secara mendalam pemahaman konsep calon guru matematika pada materi garis dan sudut. Subjek pada penelitian ini adalah mahasiswa Program Studi Pendidikan Matematika Universitas Widya Dharma Klaten yang telah memperoleh mata kuliah geometri. Subjek dipilih dari kelompok mahasiswa semester akhir (tujuh) yang akan menempuh skripsi. Hal ini dikarenakan mahasiswa telah menempuh semua mata kuliah geometri (geometri dasar, geometri analitik bidang, geometri analitik ruang, dan geometri transformasi). Sebelum mahasiswa tersebut lulus, perlu dilakukan penelitian untuk menganalisis pemahaman siswa tentang materi garis dan sudut. Setelah diperoleh informasi dari hasil penelitian, maka dosen dapat memanfaatkan informasi tersebut untuk memperbaiki metode pembelajaran dengan mengacu pada referensi yang benar. Subjek dipilih berdasarkan teknik purposive sampling. Pertimbangan yang digunakan untuk penelitian ini yaitu mahasiswa telah menempuh mata kuliah geometri dan mahasiswa yang dapat mengungkapkan ide baik secara lisan maupun tertulis. Pertimbangan tersebut bertujuan untuk mendapatkan subjek yang dapat mengomunikasikan pendapat secara lancar. Dengan demikian, didapatkan informasi yang lengkap untuk menggambarkan pemahaman mahasiswa sebagai calon guru matematika pada materi garis dan sudut. Sebelum subjek tersebut diambil untuk diwawancarai, semua subjek diberi tes pemahaman tentang materi garis dan sudut. Berdasarkan analisis hasil tes pemahaman tersebut diperoleh informasi bahwa dari 18 subjek penelitian, skor rata-ratanya adalah 4,4 dan skor maksimal jika benar semua adalah 25. Nilai maksimal yang diperoleh subjek adalah 7 dan skor minimalnya yang diperoleh subjek adalah 2. Pada penelitian ini diambil tiga mahasiswa sebagai subjek penelitian dengan kode S1, S2 dan S3 dengan mengacu pada pertimbangan pemilihan subjek penelitian yang telah disebutkan.

Metode yang digunakan untuk mengambil data pada penelitian ini adalah metode tes dan metode wawancara. Metode tes digunakan untuk memperoleh deskripsi tentang pemahaman subjek terhadap materi garis dan sudut secara kuantitatif. Pada penelitian ini digunakan tes pemahaman untuk memperoleh data tersebut. Tes pemahaman tersebut berbentuk uraian. Metode wawancara digunakan untuk memperoleh deskripsi tentang pemahaman subjek terhadap materi garis dan sudut secara kualitatif disertai dengan penyebabnya.

Instrumen yang digunakan pada penelitian ini adalah tes pemahaman dan pedoman wawancara. Tes pemahaman ini terdiri dari 6 aspek dan masing-masing aspek dibuat 1 butir soal. Keenam aspek tersebut adalah: (1) mengidentifikasi garis dan bukan garis; (2) menentukan jenis segitiga berdasarkan besar sudutnya jika diketahui ukuran ketiga sisinya; (3) mengidentifikasi sudut dari gambar perpotongan sekumpulan garis; (4) menganalisis kesejajaran dua garis pada segiempat disertai dengan alasannya; (5) menganalisis kesamaan panjang diagonal dari jajargenjang; dan (6) menganalisis kesamaan besar sudut yang berhadapan pada jajargenjang. Soal tes pemahaman tersebut ditunjukkan pada Gambar 1. 


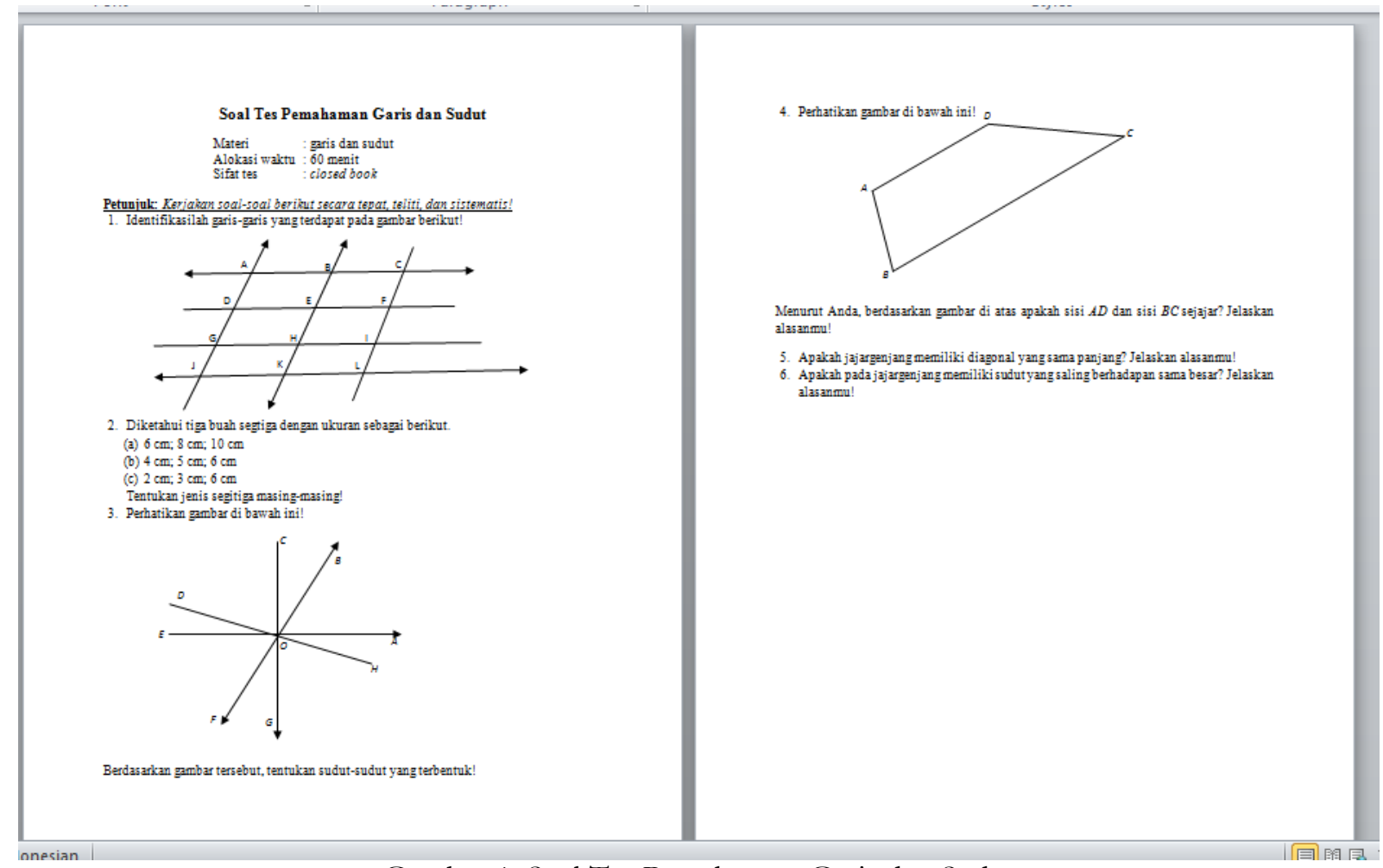

Gambar 1. Soal Tes Pemahaman Garis dan Sudut

Wawancara digunakan untuk memperoleh informasi yang mendalam tentang pemahaman mahasiswa mengenai materi garis dan sudut. Jenis pertanyaan yang digunakan dalam wawancara adalah pertanyaan yang tidak terstruktur. Sebelum wawancara dilaksanakan, perlu disusun pedoman wawancara supaya isi wawancara lebih terfokus dan tidak menyebar.

Pada penelitian ini, pemeriksaan data yang dilakukan untuk mendapatkan tingkat kepercayaan (kredibilitas) data melalui triangulasi dengan metode. Triangulasi metode yang dimaksud pada penelitian adalah pengecekan derajat kepercayaan hasil penelitian dengan membandingkan hasil tes pemahaman dengan hasil wawancara. Apabila dari hasil triangulasi tidak ditemukan kontradiksi, maka data tersebut menjadi data yang dapat dipercaya (kredibel) untuk mendeskripsikan pemahaman mahasiswa sebagai calon guru matematika pada materi garis dan sudut.

Setelah data hasil tes pemahaman diperoleh, kemudian hasil pekerjaan siswa dikoreksi dengan panduan kunci jawaban. Tahap berikutnya setiap butir soal diiberi skor sesuai dengan rubrik penilaian. Selanjutnya dilakukan analisis setiap item soal dengan menggunakan rumus berikut.

Keterangan:

$$
p_{i}=\frac{J_{i}}{n \times s_{i}} \times 100 \%
$$

$p_{i}$ menyatakan persentase banyaknya subjek yang menjawab benar pada butir soal ke-i.

$J_{i}$ menyatakan jumlah skor yang diperoleh seluruh subjek pada butir soal ke-i.

$n$ menyatakan banyaknya subjek

$S_{i}$ menyatakan skor maksimal pada butir soal ke-i.

Setelah diperoleh data deskripsi pemahaman subjek secara kuantitatif, langkah selanjutnya adalah menganalisis hasil wawancara dengan membandingkannya dengan hasil tes pemahaman. Proses analisis data wawancara pada penelitian ini dilakukan berdasarkan model Miles dan Huberman dalam Sugiyono [13], yang meliputi reduksi data, penyajian data dan penarikan kesimpulan. Berikut adalah langkah analisis data wawancara pada penelitian ini.

(1) Membuat transkrip verbal dari hasil rekaman yang disebut protokol. 
(2) Menelaah seluruh data dari sumber data verbal dari hasil wawancara, catatan lapangan, dan hasil pekerjaan subjek.

(3) Membuat reduksi data yaitu membuat rangkuman dengan menjaga data tetap di dalamnya dengan membuat segmentasi atau pengkategorian.

(4) Menyusun satuan-satuan analisis data berdasarkan aspek pemahaman mahasiswa pada materi garis dan sudut.

(5) Menganalisis dan menggambarkan deskripsi pemahaman mahasiswa pada materi garis dan sudut.

(6) Menganalisis temuan-temuan menarik.

Data yang diperoleh digunakan untuk menjawab rumusan masalah yaitu deskripsi pemahaman mahasiswa program studi pendidikan matematika sebagai calon guru matematika pada materi garis dan sudut.

\section{HASIL DAN PEMBAHASAN}

Berdasarkan hasil perhitungan data hasil tes pemahaman mahasiswa pada materi garis dan sudut diperoleh persentase banyak subjek yang menjawab dengan benar seperti yang ditunjukkan pada Tabel 1 berikut.

Tabel 1. Deskripsi Tingkat Pemahaman Mahasiswa pada Materi Garis dan Sudut

\begin{tabular}{clc}
\hline No. & \multicolumn{1}{c}{ Aspek } & Persentase \\
\hline 1 & $\begin{array}{l}\text { Mengidentifikasi garis dan bukan garis } \\
2\end{array}$ & $\begin{array}{l}\text { Menentukan jenis segitiga berdasarkan besar sudutnya jika } \\
\text { diketahui ukuran ketiga sisinya } \\
24,07 \%\end{array}$ \\
3 & $\begin{array}{l}\text { Mengidentifikasi sudut dari gambar perpotongan } \\
\text { sekumpulan garis }\end{array}$ & $25,00 \%$ \\
4 & $\begin{array}{l}\text { Menganalisis kesejajaran dua garis pada segiempat disertai } \\
\text { dengan alasannya }\end{array}$ & $23,61 \%$ \\
5 & $\begin{array}{l}\text { Menganalisis kesamaan panjang diagonal dari jajargenjang } \\
6\end{array}$ & $\begin{array}{l}\text { Menganalisis kesamaan besar sudut yang berhadapan pada } \\
\text { jajargenjang }\end{array}$ \\
\hline
\end{tabular}

Berdasarkan informasi yang terdapat pada Tabel 1 tersebut, dapat dikatakan bahwa pemahaman subjek pada materi garis dan sudut masih rendah.

Berdasarkan hasil tes pemahaman materi garis dan sudut diperoleh hasil pekerjaan subjek penelitian S1pada soal nomor 1 yang ditunjukkan pada Gambar 2.

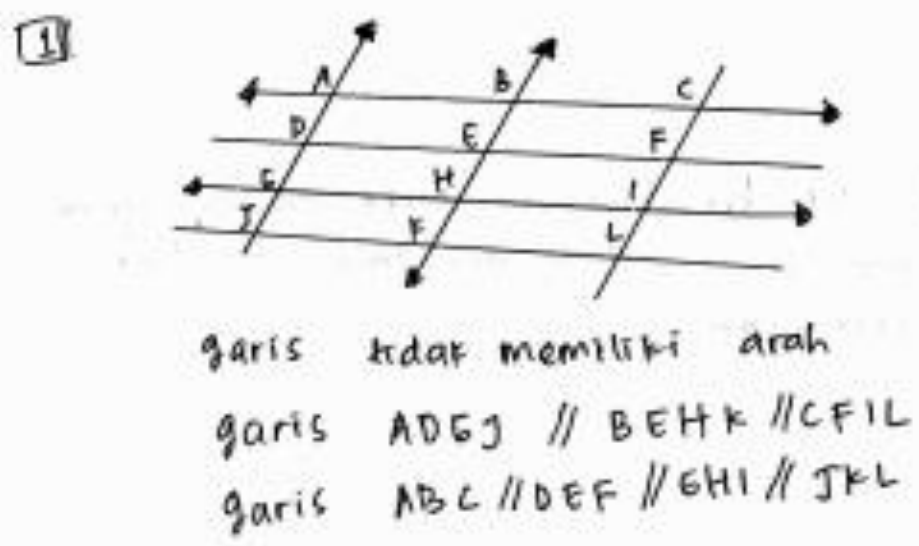

Gambar 2. Jawaban Subjek S1 untuk Soal Nomor 1

Berdasarkan Gambar 2, diperoleh informasi bahwa subjek S1 tidak menyebutkan mana yang termasuk garis dan mana yang bukan termasuk garis. Subjek S1 menyebutkan garis tidak memiliki arah dan 
menyebutkan garisnya dengan tiga dan empat huruf kapital. Berdasarkan hasil tersebut diprediksikan subjek S1 belum mengetahui definisi tentang garis.

Berikut disajikan petikan wawancara antara peneliti dengan subjek S1 untuk soal nomor 1, dimana peneliti diberi kode P. Kode S1-1-001 mempunyai arti S1 menyatakan subjek S1, 1 menyatakan soal nomor 1, dan 001 menyatakan protokol wawancara nomor 1 pada bagian tersebut.

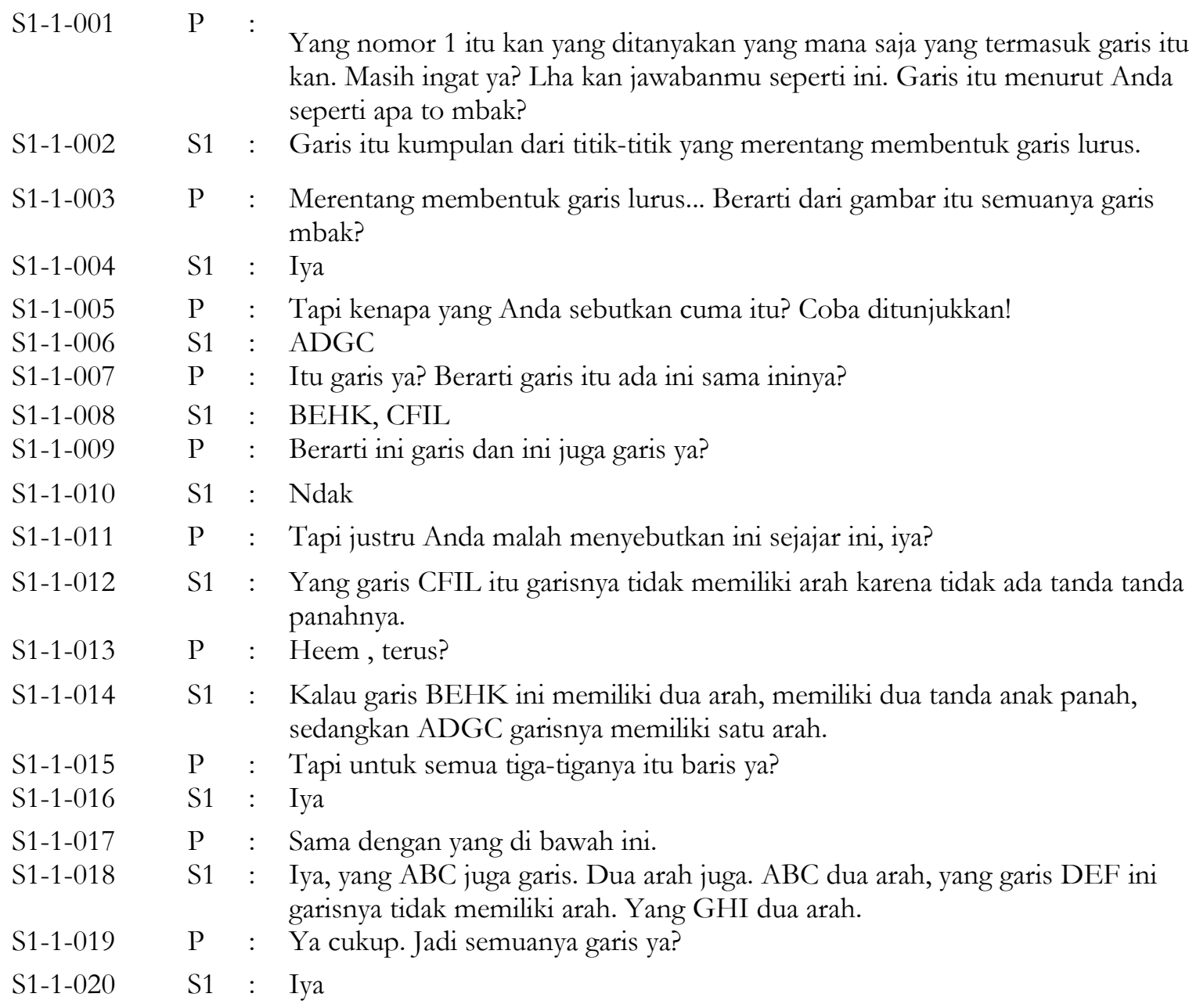

Berdasarkan petikan wawancara tersebut diperoleh informasi bahwa subjek S1 menganggap bahwa semua yang terdapat pada gambar soal nomor 1 merupakan garis. Menurut subjek S1 garis ada yang memiliki arah dan ada yang tidak memiliki arah. Berdasarkan informasi yang diperoleh dari jawaban subjek S1 dan wawancara pada soal nomor 1 dapat dikatakan bahwa subjek S1 belum mengetahui definisi garis yang benar. Definisi garis yang sebenarnya adalah himpunan titik-titik yang tidak mempunyai titik pangkal dan titik ujung. Artinya, garis mempunyai ukuran panjang yang tidak berhingga.

Berdasarkan hasil tes pemahaman materi garis dan sudut diperoleh hasil pekerjaan subjek penelitian S2 pada soal nomor 4 yang ditunjukkan pada Gambar 3. 


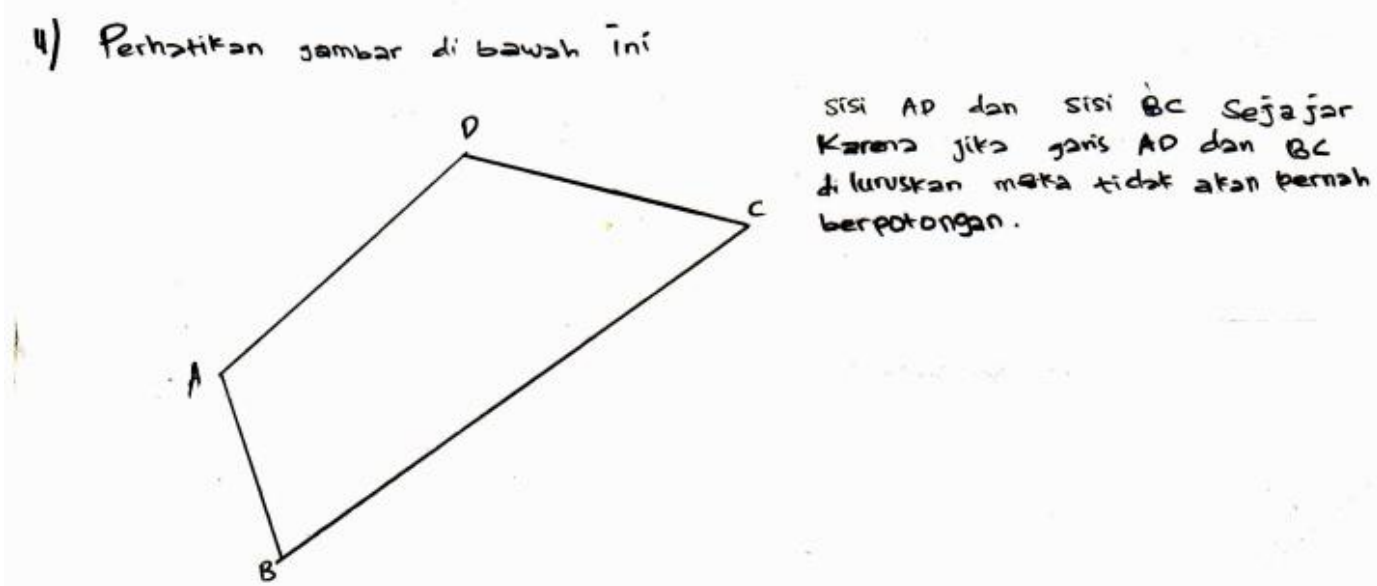

Gambar 3. Jawaban Subjek S2 untuk Soal Nomor 4

Berdasarkan Gambar 3, diperoleh informasi bahwa subjek S2 menyatakan sisi AD dan sisi BC sejajar, karena dia meyakini jika kedua sisi tersebut diperpanjang maka keduanya tidak akan pernah berpotongan. Subjek S2 diprediksi bisa menyatakan kesejajaran dua sisi dan mempunyai keyakinan jika kedua sisi tersebut diperpanjang maka tidak akan pernah bertemu, akan tetapi dia masih kesulitan untuk membuktikan keyakinannya tersebut.

Berikut disajikan petikan wawancara antara peneliti dengan subjek S2 untuk soal nomor 4.

S2-4-001 P : Coba dibaca lagi soal nomor 4 mbak.

S2-4-002 S2 : Apakah sisi AD dan BC sejajar?

S2-4-003 P : Jawabannya?

S2-4-004 S2 : Iya, sisi AD sejajar dengan sisi BC

S2-4-005 P : Mengapa?

S2-4-006 S2 : Karena jika diperpanjang sisi AD dan BC tidak akan pernah berpotongan.

S2-4-007 P : Gitu...? Yakin? Tau cara membuktikannya?

S2-4-008 S2 : Iya yakin Pak, tapi saya bingung membuktikannya Pak..

Berdasarkan petikan wawancara dengan subjek S2 untuk soal nomor 4, diperoleh informasi bahwa subjek S2 mampu menyatakan kesejajaran dua sisi dan meyakininya jika diperpanjang keduanya tidak akan pernah bertemu. Subjek S2 juga masih bingung untuk membuktikan keyakinannya tersebut. Berdasarkan hasil jawaban dan wawancara dengan subjek S2 tentang soal nomor 4, dapat dikatakan bahwa subjek menyatakan kesejajaran dua sisi dari suatu segiempat hanya dengan mengamati gambar dan meyakini argumen yang diberikan tetapi masih bingung untuk membuktikannya.

Berdasarkan hasil tes pemahaman materi garis dan sudut diperoleh hasil pekerjaan subjek penelitian S3 pada soal nomor 3 yang ditunjukkan pada Gambar 4.

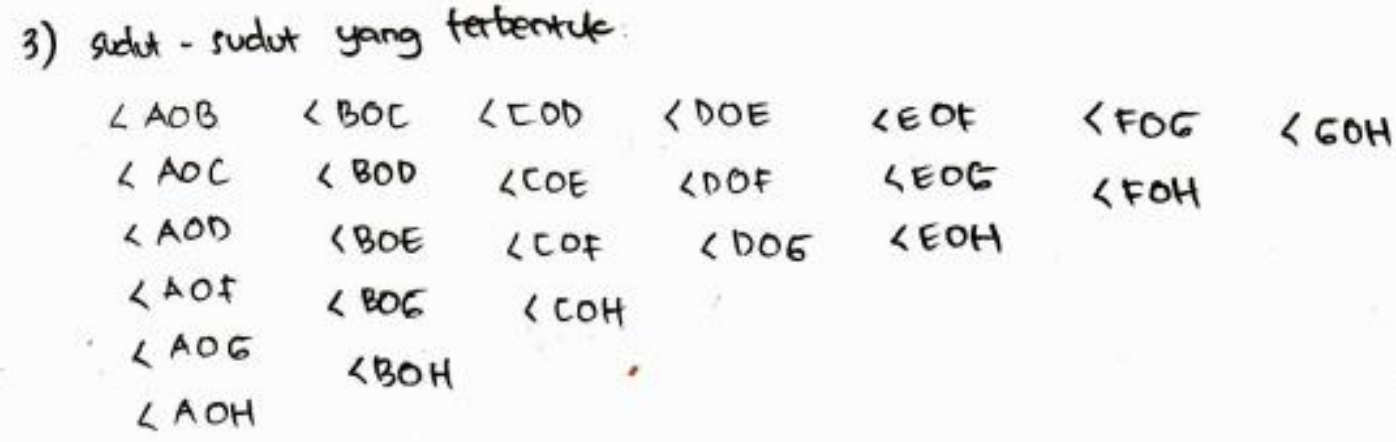

Gambar 4. Jawaban Subjek S3 untuk Soal Nomor 3

Berdasarkan Gambar 4, diperoleh informasi bahwa subjek S3 memasukkan hampir semua objek ke dalam sudut, baik yang mempunyai sinar garis maupun yang tidak mempunyai sinar garis. Contoh yang mempunyai sinar garis, subjek S3 menuliskan $\angle A O B$. Contoh yang tidak mempunyai sinar garis, subjek S3 
menuliskan $\angle C O D$. Berdasarkan informasi tersebut, diprediksikan subjek S3 belum mengerti tentang definisi sudut yang benar. Sudut terbentuk dari perpotongan sinar garis. Sehingga yang tidak terdapat sinar garisnya bukan merupakan sudut.

Berikut disajikan petikan wawancara antara peneliti dengan subjek S3 untuk soal nomor 3

S3-3-001 P : Kita lanjutkan yang nomor tiga mbak

S3-3-002 S3 : Karena sudut yang terbentuk banyak, ini saya urutkan sudut dari yang terkecil dulu, yang AOB, terus AOB saya tarik satu per satu biar bisa dibentuk sudutsudut.

S3-3-003 P : Maksudnya?

S3-3-004 S3 : Ini saya urutkan Pak, AOB,AOC, AOD. Jadi saya mengambil dua titik. Kemudian saya hubungkan dengan titik yang lain.

S3-3-005 P : Oooowww.

S3-3-006 S3 : Jadi, urut dari AOB. Kalau sudah sampai AOH, nanti tak kasih BOC, BOD, $\mathrm{BOH}$.

S3-3-007 P : Bilang saja semuanya itu sudut..

S3-3-008 S3 : Iya...

Berdasarkan hasil wawancara dengan subjek S3 untuk soal nomor 3, diperoleh informasi bahwa subjek S3 menyebutkan bahwa semua objek yang terbentuk merupakan sudut, baik yang mempunyai sinar garis maupun yang tidak mempunyai sinar garis. Berdasarkan hasil jawaban dan wawancara dengan subjek S3 untuk soal nomor 3, dapat dikatakan bahwa subjek S3 belum mengerti tentang definisi sudut yang benar.

Berdasarkan hasil analisis data tes pemahaman diperoleh informasi tingkat pemahaman mahasiswa pada aspek mengidentifikasi garis dan bukan garis adalah 9,26\%. Hasil tersebut didukung dengan hasil analisis wawancara yang menyatakan bahwa mahasiswa belum mengetahui definisi dan konsep garis. Mahasiswa masih menganggap bahwa ruas itulah yang merupakan garis. Definisi garis yang sebenarnya adalah himpunan titik-titik yang tidak mempunyai titik pangkal dan titik ujung. Artinya, garis mempunyai ukuran panjang yang tidak berhingga. Terdapat tiga hal yang perlu diperhatikan berkaitan dengan garis, yaitu garis, sinar garis dan ruas garis. Sinar grais merupakan himpunan titik-titik yang mempunyai titik pangkal dan tidak mempunyai titik ujung. Sedangkan ruas garis adalah himpunan titik-titik yang mempunyai titik pangkal dan titik ujung. Ruas garis mempunyai ukuran panjang tertentu. Hasil penelitian pada aspek ini relevan dengan hasil penelitian Imswatama dan Muhassanah [4] yang menyatakan bahwa mahasiswa kesulitan dalam mengerjakan soal yang berkaitan dengan konsep garis dan lingkaran.

Berdasarkan hasil analisis data tes pemahaman diperoleh informasi tingkat pemahaman mahasiswa pada aspek menentukan jenis segitiga berdasarkan besar sudutnya jika diketahui ukuran ketiga sisinya adalah $24,07 \%$. Hasil tersebut didukung dengan hasil analisis wawancara yang menyatakan bahwa mahasiswa belum mengetahui syarat terbentuknya segitiga jika diketahui ukuran ketiga sisinya, serta belum mengetahui rumus yang efektif dalam menentukan jenis segitiga berdasarkan besar sudutnya. Untuk menentukan jenis segitiga berdasarkan besar sudutnya jika diketahui ketiga ukuran sisinya, langkah awal yang perlu dilakukan adalah mengecek apakah dengan ukuran ketiga sisi yang diketahui tersebut dapat membentuk sebuah segitiga. Syarat terbentuknya segitiga adalah jumlah ukuran panjang kedua sisinya harus lebih besar dari ukuran sisi yang lainnya. Langkah selanjutnya adalah menentukan jenis segitiga berdasarkan besar sudutnya. Caranya adalah dengan menggunakan rumus hubungan jumlah kuadrat panjang kedua sisi segitiga dengan kuadrat panjang sisi terpanjang. Apabila jumlah kuadrat panjang kedua sisi segitiga sama dengan kuadrat panjang sisi terpanjang, maka jenis segitiga tersebut adalah segitiga siku-siku. Apabila jumlah kuadrat panjang kedua sisi segitiga lebih besar dari kuadrat panjang sisi terpanjang, maka jenis segitiga tersebut adalah segitiga lancip. Apabila jumlah kuadrat panjang kedua sisi segitiga kurang dari kuadrat panjang sisi terpanjang, maka jenis segitiga tersebut adalah segitiga tumpul. Selain dengan menggunakan rumus juga terdapat cara lain yaitu dengan menggambarnya dengan bantuan penggaris dan jangka.

Berdasarkan hasil analisis data tes pemahaman diperoleh informasi tingkat pemahaman mahasiswa pada aspek mengidentifikasi sudut dari gambar perpotongan sekumpulan garis adalah $25 \%$. Hasil tersebut didukung dengan hasil analisis wawancara yang menyatakan bahwa mahasiswa belum mengetahui definisi sudut. Hal ini mengakibatkan mahasiswa belum bisa mengidentifikasi sudut dan bukan sudut. Mahasiswa masih belum memahami bahwa sudut terbentuk dari dua sinar garis yang kedua titik pangkalnya berhimpit. 
Mahasiswa tidak memperhatikan ada tidaknya dua tanda panah. Mahasiswa masih menganggap semua yang ada pada gambar tersebut merupakan sudut, baik yang ada tanda panahnya maupun tidak ada tanda panahnya.

Berdasarkan hasil analisis data tes pemahaman diperoleh informasi tingkat pemahaman mahasiswa pada aspek menganalisis kesejajaran dua garis pada segiempat disertai dengan alasannya adalah $23,61 \%$. Hasil tersebut didukung dengan hasil analisis wawancara yang menyatakan bahwa mahasiswa beragumen tentang kesejajaran dua garis hanya berdasarkan gambar dan hal itu cukup untuk membuatnya yakin akan argumennya. Alasan yang diberikan belum memberikan bukti yang kuat untuk mendukung argumennya tersebut. Mahasiswa masih kesulitan untuk membutktikan argumennya tersebut. Kesulitan tersebut dapat disebabkan oleh kurangnya pemahaman mahasiswa tentang bukti, konsep dan prinsip matematika [14] [1] [15]. Untuk menentukan kesejajaran dua garis tidak cukup hanya dengan melihat gambar saja. Akan tetapi perlu dianlisis dengan menggunakan bantuan garis lurus yang memotong kedua garis tersebut. Kemudian gunakan teorema yang menyatakan bahwa apabila sudut sehadap yang terbetuk dari perpotongan sebuah garis dengan garis tersebut memiliki ukuran yang sama besar, maka kedua garis tesebut dapat dikatakan sejajar.

Berdasarkan hasil analisis data tes pemahaman diperoleh informasi tingkat pemahaman mahasiswa pada aspek menganalisis kesamaan panjang diagonal dari jajargenjang adalah 5,56\%. Hasil tersebut didukung dengan hasil analisis wawancara yang menjelaskan bahwa mahasiswa menyatakan kedua diagonal jajargenjang sama panjang dengan disertai alasan yang tidak akurat untuk mendukung pernyataannya tersebut. Hal ini dikarenakan mahasiswa tidak melakukan analisis terlebih dahulu tentang besar sudut jajargenjang untuk menentukan sama atau tidaknya ukuran panjang kedua diagonal jajargenjang. Seharusnya perlu dilakukan analisis tentang besar sudut jajargenjang terlebih dahulu. Apabila besar sudut-sudut jajargenjang 90 derajat, maka akan membentuk sebuah persegipanjang yang mengakibatkan ukuran panjang keduanya diagonalnya sama. Apabila besar sudut-sudut jajargenjang bukan 90 derajat, maka ukuran panjang keduanya diagonalnya tidak sama. Hasil penelitian pada aspek ini relevan dengan hasil penelitian Ayvaz, Gündüz dan Bozkuş [2] menyebutkan bahwa calon guru matematika mengalami kesulitan dalam memahami konsep diagonal segiempat. Calon guru matematika tersebut juga mengalami kesulitan dalam membuktikan argumentasi, meskipun argumentasinya tersebut benar.

Berdasarkan hasil analisis data tes pemahaman diperoleh informasi tingkat pemahaman mahasiswa pada aspek menganalisis kesamaan besar sudut yang berhadapan pada jajargenjang adalah 13,89\%. Hasil tersebut didukung dengan hasil analisis wawancara yang menjelaskan bahwa mahasiswa mampu menyatakan pada jajargenjang sudut yang saling berhadapan sama besar. Mahasiswa mencoba memberikan alasan dari pernyataan yang diberikan. Akan tetapi, alasan tersebut belum disertai dengan bukti yang lengkap untuk menguatkan pernyataannya. Untuk membuktikannya, dapat menggunakan hubungan sudut-sudut yang terbentuk dari perpotongan sebuah sisi dengan dua sisi yang sejajar pada jajargenjang. Selain itu, dapat juga menggunakan kekonkruenan dua segitiga yang terbentuk dengan memotong jajargenjang berdasarkan diagonalnya. Hasil penelitian pada aspek ini sejalan dengan hasil penelitian Yuwono [1] yang menyatakan bahwa mahasiswa mengalami kesulitan menerapkan konsep kesebangunan bangun datar untuk menyelesaikan soal.

\section{SIMPULAN DAN SARAN}

Simpulan pada penelitian ini adalah (1) tingkat kemampuan mahasiswa sebagai calon guru matematika pada materi garis dan sudut masih rendah; (2) hal yang menyebabkan hal tersebut adalah calon guru matematika belum memahami konsep garis dan sudut dengan benar serta belum memahami konsep kesejajaran dua garis dan kekongruenan dua segitiga dengan benar.

Saran yang dapat berikan pada penelitian ini adalah (1) bagi mahasiswa pendidikan matematika sebagai calon guru matematika untuk lebih giat mempelajari konsep-konsep dasar geometri terutama garis dan sudut, serta dapat menentukan strategi atau metode yang tepat dan efektif untuk mengajarkannya kepada siswanya nanti, dan (2) bagi dosen dapat segera mengambil langkah-langkah yang tepat dan efektif untuk mengatasi kesalahpahaman terhadap konsep garis dan sudut dengan merancang strategi pembelajaran yang lebih terstruktur secara sistematis 


\section{DAFTAR PUSTAKA}

[1] M. R. Yuwono, "Analisis Kesulitan Mahasiswa Dalam Menyelesaikan Soal Geometri Berdasarkan Taksonomi Bloom Dan Alternatif Pemecahannya," Beta, vol. 9, no. 2, pp. 111-133, 2016, doi: https://doi.org/10.20414/betajtm.v9i2.7.

[2] Ü. Ayvaz, N. Gündüz, and F. Bozkuş, "Understanding Of Prospective Mathematics Teachers Of The Concept Of Diagonal," J. Math. Educ., vol. 8, no. 2, pp. 165-184, Feb. 2017, doi: 10.22342/jme.8.2.4102.165-184.

[3] D. Tarigan, "Taksonomi Solo dalam Analisis Kesalahan Menyelesaikan Soal Geometri Bagi Mahasiswa PGSD," J. Pengabdi. Kpd. Masy., vol. 20, no. 75, pp. 34-39, 2014.

[4] A. Imswatama and N. Muhassanah, "Analisis Kesulitan Mahasiswa Dalam Menyelesaikan Soal Geometri Analitik Bidang Materi Garis Dan Lingkaran.," in Makalah diseminarkan di Seminar Nasional Matematika dan Pendidikan Matematika UNY, 2015.

[5] T. Ada and A. Kurtuluş, "Students' misconceptions and errors in transformation geometry," Int. J. Math. Educ. Sci. Technol., vol. 41, no. 7, pp. 901-909, Oct. 2010, doi: 10.1080/0020739X.2010.486451.

[6] S. Z. Sholihah and E. A. Afriansyah, "Analisis Kesulitan Siswa dalam Proses Pemecahan Masalah Geometri Berdasarkan Tahapan Berpikir Van Hiele," Mosharafa J. Pendidik. Mat., vol. 6, no. 2, pp. 287 298, 2017, doi: 10.31980/MOSHARAFA.V6I2.317.

[7] M. Mutia, "Analisis Kesulitan Siswa SMP dalam Memahami Konsep Kubus Balok dan Alternatif Pemecahannya," Beta J. Tadris Mat., vol. 10, no. 1, p. 83, Jun. 2017, doi: 10.20414/betajtm.v10i1.107.

[8] M. R. Yuwono, "Materi Segitiga Dan Alternatif Pemecahannya," Magistra, no. 95, pp. 14-25, 2016.

[9] R. Mahdayani, "Analisis Kesulitan Siswa Dalam Pemecahan Masalah Matematika Pada Materi Aritmetika, Aljabar, Statistika, Dan Geometri,” Pendas Mahakam J. Pendidik. Dasar, vol. 1, no. 1, pp. 86-98, Dec. 2016.

[10] M. Herfa Maulina Dewi Soewardini, "Kesulitan Belajar Garis Berat Segitiga Berdasar Aktifitas Siswa Dan Teori Piaget," Gammath J. Ilm. Program Studi Pendidik. Mat., vol. 2, no. 2, Aug. 2017, doi: 10.32528/GAMMATH.V2I2.692.

[11] A. Özerem, "Misconceptions In Geometry And Suggested Solutions For Seventh Grade Students," Int. J. New Trends Arts Sports Sci. Educ., vol. 1, no. 4, 2012.

[12] C. Biber, A. Tuna, and S. Korkmaz, "The Mistakes and The Misconceptions ff The Eighth Grade Students on The Subject of Angles," Eur. J. Sci. Math. Educ., vol. 1, no. 2, pp. 50-59, 2013.

[13] Sugiyono, Metode Metode penelitian kuantitatif, kualitatif, dan Re D. Bandung: Alfabeta, 2012.

[14] I. Minggi, D. Paduppai, and S. F. Assagaf, "Penyebab Kesulitan Mahasiswa dalam Pembuktian Matematika," J. Penelit. Pendidik. INS ANI, vol. 19, no. 1, pp. 18-22, 2016.

[15] E. F. Ningsih, "Proses berpikir mahasiswa dalam pemecahan masalah aplikasi integral ditinjau dari kecemasan belajar matematika (Math Anxiety)," Iqra', vol. 1, no. 2, pp. 191-27, 2016. 
Numerical: Jurnal Matematika dan Pendidikan Matematika, Vol. 3 No. 2 Desember 2019, 83-94

Udiyono, Muhammad Ridlo Yuwono

[Halaman ini sengaja dikosongkan] 